\title{
From Broken Communication to the Technique of (Linguistic) Anamorphosis. Edwin Morgan's Concrete Poetry ${ }^{1}$
}

Like perspectives which rightly gaz'd upon show nothing but confusion; ey'd awry distinguish form

William Shakespeare

\section{Concrete Poetry as Arrière Garde}

In one of the first concrete poetry manifestos, "From Line to Constellation", Gomringer (1954) proposed that poetry might offer a strictly non-individualistic approach to the fundamental elements of language. In Gomringer's terms, concrete poetry would constitute "a reality in itself and not a poem about something or other" (qtd. in Solt 1970: 67). "Perceived visually as a whole as well as in its parts", this sort of elementary textual composition was conceived of as "an arrangement, and at the same time a play-area of fixed dimensions" (qtd. in Solt 1970: 67), within which the reader's eye could freely roam - or "play" - across its extra-linear structure. Emphasizing its formal, material qualities, Gomringer's subsequent manifesto, "Concrete Poetry" (1956), specified that the concrete poem should function first and foremost as "a linguistic structure" rather than as "a valve for the release of all sorts of emotions and ideas" (qtd. in Solt 1970: 67-68). ${ }^{2}$

1 A substantially expanded version of this essay was published in Monika Kocot, Playing Games of Sense in Edwin Morgan's Writing. Frankfurt am Main: Peter Lang, 2016.

2 To some extent, then, concrete poetry anticipates the equally linguistic structural values advocated by Roland Barthes in the mid sixties in essays such as "The Death of 
As Bense puts it, concrete poetry "produces neither the semantic nor the aesthetic sense of its elements, words for example, through the traditional formation of linear and grammatically ordered contexts, but which insists upon visual and surface connectives" (qtd. in Solt 1970: 73). The word is not used primarily as an intentional carrier of meaning, but as a material element of construction. "Simultaneity of the semantic and aesthetic functions of words", Bense observes, "occurs on the basis of simultaneous exploitation of all the material dimensions of the linguistic elements which, of course, can also appear to be broken into syllables, sounds, morphemes or letters to express the aesthetic dependence of the language upon their analytical and syntactical possibilities. In this sense it is the constructive principle of concrete poetry alone which uncovers the material wealth of language" (qtd. in Solt 1970: 73).

The "extra-linear" or non-linear character of concrete poetry, combined with non-individualistic approach to language, let alone decontextualisation "policy", might suggest that the relationships functioning within imagery/ construal of linear poetry are going to be questioned and eventually suspended.

In "Pilot Plan For Concrete Poetry" we read that concrete poetry can be classified as either dynamic or static, representational or nonrepresentational; some poems may be seen as passive exercises or as active demonstrations. The large body of Morgan's concrete texts might be seen as a rich collection of all these forms, together with various hybrid forms one can think of. In Nothing Not Giving Messages: Reflections on Work and Life, Morgan speaks of his idea of blurring the boundaries between poetry and painting, sculpture, advertising, music (1990: 256). Similarly to other (especially Brazilian) concretists, he sees concrete poetry as fundamentally indebted to experimental modernism (Kocot 2016b: 79). Interestingly, the (inextricable) links between modernist avant-garde poetics and concrete poetry as the second avant-garde, are also explored by contemporary historians and theoreticians of literature. Let us look at two examples. In the introduction to Les arrière gardes au $X X^{\mathrm{e}}$ siècle, William Marx discusses the concept of the avant-garde and he makes clear that it is inconceivable without arrière garde, a "hidden face of modernity" (2004: 6). His ideas are further developed by Marjorie Perloff who devotes one chapter of her Unoriginal Genius: Poetry by Other Means in the New Century to a comparative study of the two avant-gardes. In her opinion,

the Author" (1968), in which Barthes also more or less claimed that texts were play-areas of fixed dimensions, where "everything is to be disentangled, but nothing deciphered". 
concrete movement, or arrière garde, might be thought of as "bringing up the rear" (Bell 2012) of modernism: ${ }^{3}$

In military terms, the rear guard of the army is the part that protects and consolidates the troop movement in question; often the army's best generals are placed there. When an avant-garde movement is no longer a novelty, it is the role of the arrièregarde to complete its mission, to ensure its success (Perloff 2010: 53).

For Perloff, concrete poetry was at the same time arrière-garde and formally innovative, with its own agenda(s) and radical/ subversive energy $^{4}$ (Kocot 2016b: 79). As Barthes puts it, "Être d'avant-garde, c'est savoir ce qui est mort; être d'arrière garde, c'est l'aimer encore" ["To be avant-garde is to know that which has died. To be arrière garde, is to continue to love it"] (qtd. in Marx 2004: 99).

Morgan was surely drawn to modernist avant-gardes: to the ideograms of Pound and Fenollosa, Marinetti's parole in libertà and to Russian modernists: Vasily Kamensky's "ferroconcrete poems", Ilya Zdanevich's and Velimir Khlebnikov's zaum, as well as Vladimir Mayakovsky's language poetry. But, at the same time, he saw the concrete as connected with the here-and-now and fast-travelling communication:

I'm interested in concrete poetry as an extension of technique. It's a new instrument which you have to learn to play. You have to find out what it can do and what it can't do. As a language it can be very dense and compressed or very light and delicate, and yet both of these different characteristics are held within a common ideogrammatic quality which seems peculiarly right at the present time. I mean that it's a system of signs, of striking and uncluttered flashes of language which find their place in a world of multiplex and speeded-up communications (Glasgow University Special Collections Acc 4848 / Box 69 Concrete / Sound Poetry).

${ }^{3}$ The point here is that whereas the Surrealists were concerned with "new" artistic content - dreamwork, fantasy, the unconscious, political revolution - the concrete movement always emphasized the transformation of materiality itself. Hence the chosen pantheon included Futurist artworks and Finnegans Wake, Joaquim de Sousa Andrade's pre-Modernist collage masterpiece The Inferno of Wall Street (1877), and the musical compositions of Anton Webern, Pierre Boulez, Karlheinz Stockhausen, and John Cage (Perloff 2010: 67-68).

${ }^{4}$ Commenting on the paradoxical nature of concrete poetry, Perloff writes:

Here is the important distinction between avant- and arrière-garde. The original avant-garde was committed not to recovery but discovery, and it insisted that the aesthetic of its predecessors - say, of the poets and artists of the 1890s - was "finished". But by midcentury the situation was very different. Because the original and avant-gardes had never really been absorbed into the artistic and literary mainstream, the "postmodern" demand for total rupture was always illusory. Haroldo de Campos, following Augusto's lead, explains that the concrete movement began as rebellion - "We wanted to free poetry from subjectivism and the expressionistic vehicle" of the then poetic mode (Perloff 2010: 67). 
Morgan also connects the art of concrete with the future and scientific developments. Concrete poetry, he writes, "is definitely postexistentialist, it's reacting against the world of Kafka and Eliot and Camus and Sartre. It's more interested in Yuri Gagarin and Marshall McLuhan. It looks forward with a certain confidence. It sees a probable coming together of art and science in ways that might benefit both" (Glasgow University Special Collections Acc 4848 / Box 69 Concrete / Sound Poetry). ${ }^{5}$ As Eleanor Bell aptly notices, "it was therefore this forward and, simultaneously, backward looking nature of concrete poetry which offered Morgan [...] a new aesthetic with which to challenge 'well-known insularity' on the one hand and to explore new forms of spatiality on the other" (Bell 2012: 113). And if he praised Khlebnikov and Mayakovsky for their mind-bending imagery and juxtaposition, inventive use of word and sound in every device of onomatopoeia, alliteration, assonance and dissonance, pun and palindrome, morphological play and dislocation, then we surely find all that in his concrete experiments.

If, as David Kilburn asserts, concrete poetry "does not refer to any consciousness and is not concerned with worlds or experience, real or imaginary and is thus not ontological" (1996: 10), then the connection with mindscapes, human or otherwise, of Morgan's poetic work might show the exact opposite. Morgan sees concrete poetry as related to concrete human experience and is not concerned with its potential for producing non semantic or abstract patterns, and even if he occasionally uses such patterns he does so in order to achieve an overall semantic purpose; he sees the concrete "as an instrument of immediate communication: a flash; a blush; a burst; a curse; a kiss; a hiss; a hit; a jot; a joke; a poke; a peek; a plea; an ABC. An instrument of communication, but also an instrument of pleasure" (Glasgow

${ }^{5}$ For McLuhan, as for Morgan, verbivocovisual experimentation was inextricably linked to changes in the world "outside" of the text, to the new media of communication. Morgan's archives from this time show that he shared many views with McLuhan:

Marshall McLuhan describes [...] the movement away from the printed book, away from the linear, towards a more "open", instantaneous, spatial experience which technology has presented us with in newspaper and radio, film, TV, advertising, and in computers which offer us a kind of extension of human consciousness [...]. He says. "All the new media, including the press, are art forms that have the power of imposing, like poetry, their own assumptions. The new media are not ways of relating us to the old "real" world; they are the real world, and they reshape what remains of the old world at will". (Explorations in Communication (1960). - This, I think is relevant to concrete poetry. The concrete poem isn't meant to be something you would come across as you turned the pages of a book. It would rather be an object that you passed every day on your way to work, to school or factory, it would be in life, in space, concretely there (Special Collection Acc 4848 / Box 69). 
University Special Collections Acc 4848 / Box 69). Despite the Brazilian call "against the poetry of expression", Morgan points out that "expressionisms, individualisms, and romanticisms move in and out of concrete poetry and have to be reckoned with" (1974: 24). He acknowledges, and certainly affirms, a great range of effects in concrete poetry from "warm" to "cold". He finds some of the poems humorous and witty; some of them he deems stark and hermetic; he mentions political, religious, mathematical, sculptural poems; he affirms those two- and three-dimensional, those abstracts concrete forms such as animals, and those which concretise abstract forms such as grammatical relationships. Morgan sees most his verbivocovisual experiments on the "warm" side of the concrete (Glasgow University Special Collection 4848/21). He notices a peculiar correspondence between his own work and that of Ian Hamilton Finlay, and suggests that his humour and Finlay boats "may be of some use, both tying concrete to certain bollards of human life and human pleasure" (qtd. in McGonigal 2012: 156).

\section{Broken Communication?}

Broken communication as a cultural phenomenon is undeniably one of the major themes in Morgan's writing, and some of his best known poems exploit it, humorously in "The Computer's First Christmas Card" (Morgan 1996: 177), "The Computer's Second Christmas Card" (Morgan 1996: 142), "First Men on Mercury" (Morgan 1996: 267), "Canedolia", or "Loch Ness Monster's Song" (Morgan 1996: 248), and more seriously in the Emergent Poems.

Emergent Poems, as Morgan calls them, exemplify the poet's predilection towards playing games with quotations taken from wellknown texts of culture. Amongst "emergent" poems, there are "written through" versions of passages from Dante's Inferno ("Nightmare"), Robert Burns's "To a Mouse" ("Dialeck Piece"), Bertold Brecht's "Von der Kindesmörderin Marie Farrar" ("Plea"), Rimbaud's "Une Saison en Enfe" ("Seven Headlines"), or even Communist Manifesto. The poems' final lines, quotations from Dante, Burns, Brecht, and Rimbaud, are in the original Italian, Scots, French and German, respectively, while that from the Communist Manifesto is in Russian (though Morgan uses the Roman alphabet); all the poems which emerge are in English. Interestingly, "Message Clear" is written entirely in English, with its concluding line taken from the Gospel of John chapter 11, and it would seem to offer no visible challenge for the reader. Its title (which can read "message received", 
"message checked", "message confirmed", or obviously "simple message") suggests that the message is clear, but in close reading - and it also applies to other "emergent" texts - more and more previously omitted elements reappear as it were, which in turn might change the readers' perception as well as their projections concerning the message of the poems as such. In "emergent" poems Morgan explores the limits of communicativeness and, by transgressing them, he "makes the message clear" to the skilful reader. ${ }^{6}$

"The Computer's First Christmas Card" (below) and "The Computer's Second Christmas Card" concern the "relations that will exist between computer creativity and human creativity, the challenge to the second from the first" (Morgan 1990: 258). "The Computer's First Christmas Card" with its open spacing, and giddy warping columns of Ys and clusters of consonants, festively celebrates the machine's movement toward producing its Christmas card. It makes use of a formal grid: there are 35 lines consisting of 10 letters; in each line there are two words, each of which having consonant-vowel-double-consonant-y; and at the same time it suggests that the machine is scanning a semantic "store", all the words (for instance "jolly", "holly", "merry", "berry", "happy", "jelly" "belly") are somehow related to Christmas cheer (Morgan 1990: 258).

It goes without saying that the poem is goal-seeking, and it is equally certain that it misses its goal - even though from the poem's very beginning we are expecting the machine to produce "Merry Christmas", and even though we find lines such as "merry merry / merry merry / merry Chris", when we finally reach the end of the poem we find MERRY CHRYSANTHEMUM. Given the joyful quality of the poem, it would be difficult to agree with Jo Allen Bradham who projects quite baleful (as the title of his article suggests) quality on it: "Obliterating Christ, the techno-voice sends greeting divorced from Christmas and Christ but definitely connected with someone called Chris who joins jolly Molly, merry Harry, and merry Barry in a secular merry merry of some sort" 1987: 51). The way I see it, the computer's failure in producing the expected message points to a need of changing the perspective. When adopting a lateral perspective, we may notice that the lack of standard "Merry Christmas" is substituted with the machine's discovery of an acceptable equivalent: the chrysanthemum as a symbolic good luck flower, and also as a flower one might buy or give at Christmas.

${ }^{6}$ My in-depth analysis of the text can be found in "From Anaphoresis to Metaphoresis. Scene-graphs in Edwin Morgan's 'Message Clear'” ( Kocot 2012: 125-138), and in Playing Games of Sense in Edwin Morgan's Writing (Kocot 2016b: 55-75). 


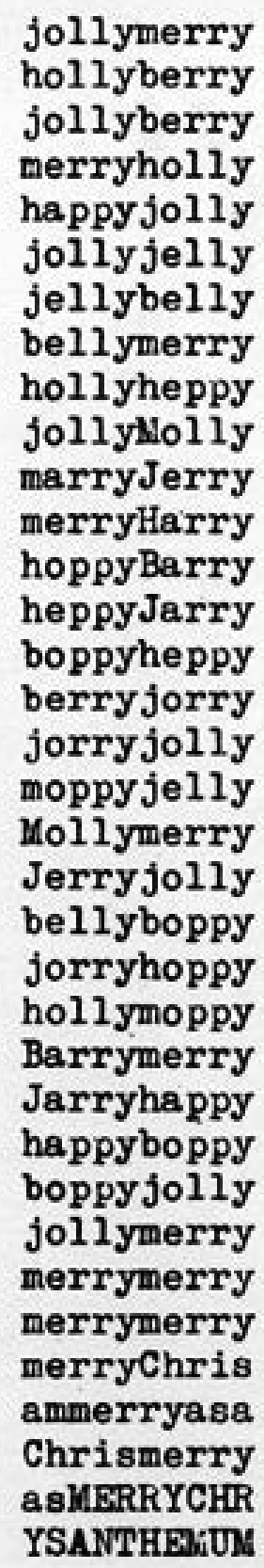

Figure 1. Edwin Morgan 1996: 177 


\section{goodk kkkkk unjam ingwe nches lass? start again goodk lassw enche sking start again kings tart! again sorry goodk ingwe ncesl ooked outas thef? unmix asloo kedou tonth effff rewri tenow goodk ingwe ncesl aslookedou tonth effff fffff unjam feast ofsai ntste venstefanç utsai ntrew ritef easto fstep toeso rryan dsons orry! start again good? yesgo odkin gwenc eslas looke dout? doubt wrong track start again goodk ingwe nceslasloo kedou tonth efeas tofst ephph phphp hphph unjam phphp repea tunja mhphp scrub carol hphph repea tscru bcaro lstop subst itute track merry chris tmasa ndgoo dnewy earin 1699? check digit banks orryi n1966 endme ssage}

Figure 2. Edwin Morgan 1996: 142

In "Computer's Second Christmas Card" (above), Morgan replaces "carefree vertical streamers" (Edgecombe 2003: 105) of the first card with a more horizontal composition, with nine columns each consisting of 5 letters / signs. The reading of the poem makes sense only when we read it from left to write in a linear fashion. But even then we notice that the poem's movements are as Edgecombe puts is "full of neurotic crunches and fussy self-revisions" (2003: 105). Whether these crunches are neurotic or simply playful games with the readers' expectations quite obviously depends on the attitude of the individual. In my opinion, the goal-seeking columnar enjambment, where the words are almost always breaking in the wrong places, foregrounds not the neurotic obsession with failure but rather the idea of openness to constructing meaning despite the obstacles on the way - the computer, as Morgan explains, has to find the carol Good King Wenceslas, ${ }^{7}$ and even though the assignment appears to be a bit problematic, the computer does not surrender: "goodk kkkkk unjam ingwe nches lass? start again goodk / lassw enche sking start again kings

7 The carol is a $19^{\text {th }}$ century translation of a Czech poem from the Catholic Bohemia. One can find traces of the first stanza of the carol in the poem:

Good King Wenceslas looked out

On the feast of Stephen

When the snow lay round about

Deep and crisp and even

Brightly shone the moon that night

Though the frost was cruel

When a poor man came in sight

Gath'ring winter fuel. 
tart! again sorry". The computer's self revisions ("with just a touch of semantic voluntarism in the outriders on Steptoe and Son, good-class wenches", 1990: 258) are very amusing indeed: "start again good? yesgo odkin gwenc eslas looke dout? / doubt wrong track start again". We can notice here the truly dialogical nature of the message - the computer asks questions ("good?") and provides answers ("yes") which, as we can see, make the poem going; additionally, the computer engages in sound games as in "looke dout? / doubt" and metatextual comments ("wrong track start again"). At some point the computer experiences some mechanical faults and decides to create a straight Christmas greeting ("lstop subst itute track merry chris tmasa") which nevertheless gets wrong until finally corrected "(tmasa ndgoo dnewy / earin 1699? check digit banks orryi n1966 endme ssage". But why does Morgan's column consist of five letters, one might ask, why not four or six? The answer can be found in Morgan's notes: "since the message here involved a narrative and not a mere phrase, I set it out in the conventional five-letter pattern used for coded messages" (1990: 259). This short quotation testifies to the fact that for Morgan the content and the form of a poetic text, even a short and insignificant one, should not be separated from its philosophy, it this case the philosophy of coded messages.

\section{Looking Awry}

The concept of "encoding" messages and composing seemingly unintelligible texts brings me to the practice of anamorphosis, ${ }^{8}$ which, as Slavoj Žižek observes, is "the element that, when viewed straightforwardly, remains a meaningless stain, but which, as soon as we look at the picture

8 The term is derived from the Greek prefix ana-, meaning back or again, and the word morphe, meaning shape or form. The most informative monograph on anamorphosis is undoubtedly Jurgis Baltrušaitis's Les perspectives depraves - anamorphoses ou Thaumaturgus opticus. When defining anamorphosis, Baltrušaitis quotes Diderot's Encyclopédie. I will refer to Cyclopaedia, or an Universal Dictionary of Arts and Sciences which gives the following definition of the term: "in perspective and painting, a monstrous projection; or a representation of some image, either on a plane or curve surface, deformed; which at a certain distance shall appear regular, and in proportion" (Chambers 1728: 84). In his insightful Pragnienie obecności: Filozofie reprezentacji od Platona do Kartezjusza, Michał Paweł Markowski devotes one of the chapters to the theme of anamorphosis, and, what seems to be of great value, he pictures it within a whole array of techniques of representation, beginning with Plato and ending with Descartes (who was an ardent practitioner of anamorphotic deformations, as can be seen in his Dioptrics). 
from a precisely determined lateral perspective, all of a sudden acquires wellknown contours" (1992: 90). . By carefully studying Morgan's Emergent Poems, we can observe how the poems are not only about written words or letters, but first and foremost the empty slots between letters and words, waiting for the reader to activate the hidden potential meanings of words and phrases. The reader is expected to pursue a processual interpretation of the category of visible / invisible, featured / non-featured, present / absent. Morgan employs here the technique of anamorphosis due to which the meanings of overt and hidden text may be questioned, de-constructed / re-constructed.

Markowski observes that anamorphosis can also refer to a given, modelled kind of cognitive perspective as well as its representations in external objects (1999: 189-200). Ślósarska adds that in literary texts, the technique of anamorphosis is usually realised along with techniques of animisation and anthropomorphisation of objects, but also together with the technique of metamorphosis of a given element of representation. Viewed in a wider perspective, the technique of anamorphosis stands as a peculiar element of the poetics of point of view (Ślósarska 2005: 72), and it might be referred to as a conceptual anamorphosis.

In 1970, Morgan publishes a series of poems called The Horseman's Word; the title of the collection is quite telling, as it refers to the ancient language understood between beasts and men (McGonigal 2012: 4). And it would seem The Horseman's Word presents a cross-cultural journey - within its small space the series of horse poems ranges across Scottish, Norse, North American, Greek, English and Hungarian sounds, images and myths. In an interview with Marshal Walker, Edwin Morgan remarked: "[a]nimals are also a part of the environment: they are there and why should the poet not try to give them voice, as it were. I think a lot of my poetry is either a straight or in some disguised form dramatic monologue, and I quite often do try to give an animal a voice just as I might give an

${ }^{9}$ In order to show the workings of anamorphosis, Žižek refers to one of the most recognisable examples of anamorphotic gaze - Holbein's Ambassadors (1533):

At the bottom of the picture, under the figures of the two ambassadors, a viewer catches sight of an amorphous, extended, "erected" spot. It is only when, on the very threshold of the room in which the picture is exposed, the visitor casts a final lateral glance at it that this spot acquires the contours of a skull, disclosing thus the true meaning of the picture - the nullity of all terrestrial goods, objects of art and knowledge that fill out the rest of the picture [...] nothing is what it seems to be, everything is to be interpreted, everything is supposed to possess some supplementary meaning. The ground of the established, familiar signification opens up; we find ourselves in a realm of total ambiguity, but this very lack propels us to produce ever new "hidden meanings"(Žižek 1992: 90-91). 
object a voice as in 'The Apple's Song', ${ }^{10}$ just to get everything speaking, as it were" (Morgan 1990: 77). And the concept of "getting everything speaking" certainly informs Morgan's lateral perspective of looking at the world; every creature and even every object may at some point be given voice and thus change the way we humans perceive our environment; in some poems, Morgan's anamorphosis, understood literally or conceptually, works as a catalyst, it successfully challenges our projections of the world we live in. We will come back to this theme in the latter part of this essay and now will focus our attention on the anamorphotic dramatic monologues.

In "Centaur", one can sense a real development through the repetition, as well as the punning and palindromic effects within the words that, in Marshall Walker's view, dramatise a mounting frustration and anger (Morgan 1990: 61). For Morgan, the poem is "a kind of dramatic monologue, like 'Message Clear,' it's 'Thoughts of a Centaur,' if you like" (Morgan 1990: 61).

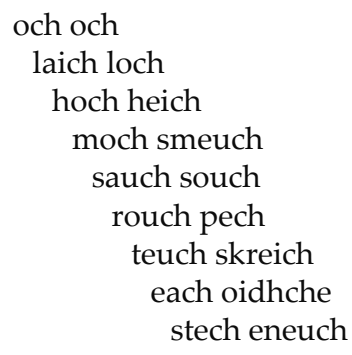

(Edwin Morgan 1996: 211)

As the thoughts of the centaur are paradoxical ("i am, horse / unhorse") it is hard to sort them out, but, as Morgan suggests, "there could very well also be a kind of agony and I think [...] this does come in the end where perhaps it moves towards being more a statement or cry from the human part of the centaur" (Morgan 1990: 61). It is interesting to notice Morgan's anamorphotic (in the sense of the anthropomorphisation of the horse) perspective in the psychological drama which is so carefully controlled and economical in its use of words. We guess that we are listening to the cry of a man who is partly horse rather than a horse which is partly man,

${ }^{10}$ Who knows what apple thinks! We don't really know - it doesn't give signs of thinking, but because we don't get signs of what an animal or a plant or a fruit is really thinking, I don't think we are entitled to just switch off and say it's not feeling or thinking. I like the idea particularly that we're surrounded by messages that we perhaps out to be trying to interpret (Morgan 1990: 131). 
as the man, it seems, would be more conscious of the animal part of him. But when at the end of the poem the speaker cries out "unhorse me!" we get the sense of the real drama of existence - there is no escape from the situation, the two creatures are one. ${ }^{11}$ The oppressive limitation having its source within the creature is expressed also in the poem's typography: "Centaur" is in the shape of a long rectangle, or metaphorically speaking a deep and narrow well; the speaker's cry visually "lying" at the bottom of the rectangle-well seems to foreground the idea of his crying out from the depth of his being; it is a dramatic cry for help (from the outside), but at the same time the shape of the poem suggests that his chances of gaining freedom as an individual are rather slim.

But a real anamorphotic treat, especially for someone with a good command of Scots is "Kelpie" (Morgan 1996: 211); the poem speaks of a Lowland Scots water-spirit usually appearing as a horse:

i am, horse

unhorse, me

i am, horse

unhorse, me

i am, horse

unhorse, me

i am, horse

unhorse, me

i am, horse

unhorse, me

i am, horse

unhorse, me

i am, horse

unhorse, me

i am horse:

unhorse me!

(Edwin Morgan 1996: 210)

There are two one-syllable words arranged in nine lines which viewed as a whole form a sort of a diagonal. The first line introduces a surprising element ("och och"), and as each line is more indented than the preceding one, we literally and metaphorically speaking step into the mythical realm. The variations on a distinctively Scottish fricative in the form of playful onomatopoeia witness as it were a scene from the myth: in the middle of the night ("each oidhche ") we find ourselves in the misty atmosphere, with mystical energy in the air ("moch smeuch"), and we witness a strange phenomenon - to the sound of rushing water,

11 See Morgan 1990: 61. 
a panting, untamed creature ("sauch souch") unexpectedly moves in the water, and possibly, emerges from the loch. The shape of the poem might then reflect Kelpie's movements in and above the water. As the poem's reception relies on Scots meanings, I have decided to quote Nicholson's list of translated words to facilitate the reading (obviously, it is merely one way of deciphering the meaning, and the reader is free to create his / her own images within the poem): "laich = low-lying; hoch $=$ hindquarters; heich = high; moch = misty atmosphere; smeuch = energy; sauch = tough; souch = sound of rushing water; rouch = untamed; pech = panting; teuch $=$ vigorous; skreich $=$ screech; oidhche $=($ Gaelic $)$ night; stech $=$ gorged; eneuch = enough" (Nicholson 2002: 93).

Scottish folklore and another instance of anamorphotic gaze can be found in "The Loch Ness Monster's Song" (Morgan 1996: 248). This poem, or a song, is an example of quite a sophisticated zaum-like play of pure sound, and, as the title suggests, the speaking " $\mathrm{I}$ " is the Loch Ness Monster him/herself:

Sssnnnwhuffffll?

Hnwhuffl hhnnwfl hnfl hfl?

Gdroblboblhobngbl gbl gl g g g g glbgl.

Drublhaflablhaflubhafgabhaflhafl $\mathrm{fl} \mathrm{fl-}$

gm grawwwww grf grawf awfgm graw gm.

Hovoplodok - doplodovok - plovodokot-doplodokosh?

Splgraw fok fok splgrafhatchgabrlgabrl fok splfok!

Zgra kra gka fok!

Grof grawff gahf?

Gombl mbl bl -

blm plm,

blm plm,

blm plm,

blp.

For Morgan, the poem is an example of a performance piece. "It absolutely demands to be read aloud", he stresses when commenting on the poem's "imagery." His expressive performances can be found on You Tube and other websites. ${ }^{12}$ Here is what the poet has to say about the structure of the poem and its message:

the way the lines are set out, the spelling, the punctuation are all devised [...] to help the performance [...]. I imagine the creature coming to the surface of the water, looking round the world, expressing his or her views, and sinking back into the loch at the end. I wanted to have the mixture of bubbling, gurgling, plopping sounds

${ }^{12}$ One of such performances can be found here: http://www.poetryarchive.org/ poetryarchive/single Poem.do?poemId=1683 [accessed May 15, 2019]. 
of water and the deep gruff throaty sounds that a large aquatic monster might be expected to make (Morgan 1990: 255).

The sound-messages and their relation to language creation, but also language deconstruction, is what draws critics to this performance piece. In his insightful analysis of poem, Edgecombe notices that "because combinations of velar plosives and liquids have a phonaesthetic connection with passage of air through water (as in 'glug') and bilabial plosives with the sudden expulsion of air (as in 'burp')" (2003: 141), it seems that the lake has reduced the monster's messages to a string of bubbles; ${ }^{13}$ in his view, "the consonantal clusters of 'The Loch Ness Monster's Song' draw on this conversion" (Edgecombe 2003: 141). Edgecombe adds that if "a fabulous monster lays claim to a voice, we shouldn't be surprised that language itself dissolves into a dialect of the irrational" (2003: 141). For W. N. Herbert the song as also a kind of literary dialect, "combining Scots sound-units [...] with those of other languages, principally East European" (1990: 73). As I argue elsewhere, the monster's song is not written in a dialect, but a language, "and it is not irrational but rather unintelligible, at least to human species" (Kocot 2016b: 118). It is interesting to see how critics respond to Morgan's sound experimentation. In her article on Morgan's multilingualism, Hanne Tange appreciates the fusion of linguistic codes through which Morgan creates a sort of world language (Tange 2004: 98), but she immediately adds that "such an absolute amalgamation can only be achieved at the cost of all sense" (2004: 98). Is that so?, one should ask. Agreeing with Tange would immediately imply that English is superior to any other language, especially given the fact that Morgan clearly, and playfully, affirms the non-anthropocentric perspective. The poem seems to celebrate the multiplicity of codes, sounds, moods, and modes of expression. In our reading of the poem, we automatically move beyond conventional sense creation (Kocot 2016b: 118). By listening to Morgan's performance, we may discover more senses than those we find on the page. We can actually hear the music of what happens. For instance, we can hear the Monster's melodious soliloquy introduced by the affirmative ("Gdroblboblhobngbl gbl gl g g g g glbgl", "gm grawwwww grf grawf awfgm graw gm"), exclamatory ("Splgraw fok fok splgrafhatchgabrlgabrl fok splfok! / Zgra kra gka fok!") and interrogative ("Sssnnnwhuffffll? / Hnwhufflhhnnwflhnflhfl?") (Kocot 2016b: 118). Nessie's temperamental nature can be noticed in the sudden change of mood, from the initial interest in the world above the water ("Sssnnnwhuffffll? / Hnwhuffl hhnnwfl hnfl hfl?") to highly expressive sounds of frustration or resentment ("Splgraw

${ }^{13}$ For a more elaborate analysis, see Kocot 2016a: 33-34; Kocot 2016b: 117-119. 
fok fok splgrafhatchgabrlgabrl fok splfok! / Zgra kra gka fok!") (Kocot 2016b: 118).

The way Nessie disappears from sight might offer another example of anamorphotic sense creation:

Gombl mbl bl -

blm plm,

blm plm,

blm plm,

blp.

If the typography of these last few lines suggest that the monster slowly sinks back into the lake, the aural design might suggest that Nessie disappears only to appear in another sense. This is where the genius of Morgan's sound instrumentation is fully in operation. As Edgecombe rightly points out, it is impossible to say "blp" without voicing the epenthetic " $\mathrm{i}$ " (2003: 141), and once we do so, "blp" transforms into "blip". Seemingly simple cluster "blp" hides as it were the moment where Nessie becomes silent and disappears from sight but suddenly appears on the radar screen (as signalled by the "blip") (Kocot 2016b: 118). Again, Morgan encourages the readers to activate various perspectives of looking at the same scene.

Last but not least, we can see examples of anamorphosis in Morgan's News poems (Morgan 1996: 117-30). Published in 1987, News poems exemplify Morgan's various experiments in anamorphotic perspectives, as he poetically recycles cut-outs from newspapers. To my mind, the poems in this collection can be seen as conceptual anamorphoses; with each newspaper article / advertisement, Morgan adopts such a perspective that the objects, in our case words, or letters, presented in new light lose their original meaning, and new forms / words / letters appear, and this is how new texts emerge. In the introduction to News poems, Morgan presents his poetic objective:

The News poems were cut out from newspaper and other ephemeral material, pasted on to sheets of paper, and photographed. Most people have probably had the experience of scanning a newspaper page quickly and taking a message from it quite different from the intended one. I began looking deliberately for such hidden messages and picking out those that had some sort of arresting quality, preferably with the visual or typographical element itself a part of the "point", though this was not always possible. What results is a series of "inventions" both in the old sense of "things found" and in the more usual sense of "things devised". (Morgan 1996: 118)

This technique may have its origin in Morgan's collections of scrapbooks into which he would paste cuttings from various sources, 
as McGonigal argues (2012: 41), but all the more important is the idea the "found object" / "found poem". We might say that this is not an implementation of Pound's "Make it New!" but Jasper Johns's "Take an Object. Do something to it. Do something else to it" (Johns 1996: 54).

Morgan composed numerous found poems, and each of them is different; some are concrete, some philosophical, political, there are also literary re-writings. We will now focus on the one which, in all its simplicity, opens more vistas than one would expect. In "Holy Flying Saucer Satori", Morgan deconstructs an essentialist view concerning seeing a flying saucer, experiencing holiness and Satori (a Buddhist term for awakening, realising one's true identity, seeing one's true nature, attaining one's Buddha-nature):

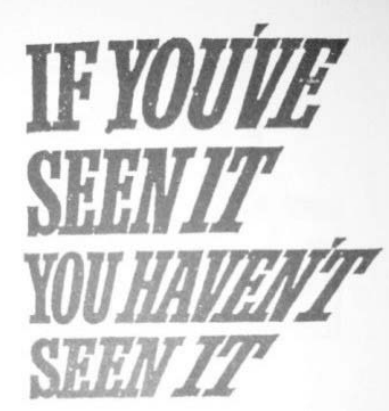

Figure 3. Edwin Morgan 1974: 63

The poem's typography resembles the $17^{\text {th }}$ century experiments in mirror anamorphosis, or possibly the famous Hans Holbein's Ambassadors. The shape of the letters is slightly distorted, they are radiating as it were from the invisible centre below the text; the letters on the left-hand side are set "straight" whereas those which follow are bent diagonally to the right. Given that the title mentions a flying saucer, the poem could be seen as a freeze frame from the video featuring a spinning UFO. Interestingly, whether in film or theatre, a freeze-frame technique is used to emphasise special moments that are considered particularly significant. In "Holy Flying Saucer Satori" we are certainly dealing with such a moment. Morgan constructs the title as a cognitive amalgam consisting of three elements: the concept of holiness, the phenomenon of UFO and the Buddhist concept of Satori. The poem itself foregrounds the issue of seeing, or to be precise the implied impossibility of seeing " $i t$ ", where " $i t$ " stands for the amalgam 
in the title. In this remarkably concise poem Morgan manages to transmit both the wisdom of Buddhist thought and the mystery of life, regardless of ancient or futurist origin - some things are unspeakable, some ideas are not transmittable by means of the senses, as it were; one cannot see beyond oneself as long as one applies a dualist perspective of the seer and the seen. Seeing is possible only when one abandons the illusion (or cognitive dissonance) of separating oneself from the object of seeing.

Morgan habitually questions standard cognitive figures by means of anamorphosis. By actively studying the imagery of his poems and their typographical design we may discover seemingly invisible dimensions of being. By means of (linguistic) anamorphosis, Morgan playfully destabilises what we know and expect in language, and very often he creates an alternative, disturbing voice whose role is to take charge and speak to us, often in a language we are not familiar with. That requires taking a different, lateral perspective of looking at things (including Morgan's poems), which in turn may bring us closer to experiencing the beauty of simple things. The messages we un/discover in our deep listening to Morgan's performances, and in mindful reading of his poems, may change our mindsets forever.

\section{References}

Bell, Eleanor (2012). “Experimenting with the Verbivocovisual: Edwin Morgan's Early Concrete Poetry". Scottish Literary Review 4 (2): 105-121.

Bradham, Jo Allen (1987). "Baleful Greetings from Morgan's 'Christmas Card"'. College Literature 14.

Chambers, Ephraim (1728). Cyclopaedia, or an Universal Dictionary of Arts and Sciences. Vol 1. London. https://archive.org/details/CyclopediachambersVolume1/page/n129/mode/2up [accessed May 25, 2014].

Edgecombe, Rodney Stenning (2003). Aspects of Form and Genre in the Poetry of Edwin Morgan. Amersham: Cambridge Scholars Press.

Hayman, David and Elliott Anderson (eds.) (1978). In the Wake of the Wake. Wisconsin: University of Wisconsin Press.

Herbert, W. N. (1990). "Morgan's Words". In: About Edwin Morgan. Eds. Robert Crawford and Hamish Whyte. (65-74). Edinburgh: Edinburgh University Press.

Johns, Jasper (1996). Writings, Sketchbook Notes, Interviews. Ed. Kirk Varnedoe. New York: Museum of Modern Arts / Harry N. Abrams.

Kilburn, David (1996). “Type is Honey". Mermaid 35 (3) (Jan.): 9-11.

Kocot, Monika (2012). "From Anaphoresis to Metaphoresis. Scene-graphs in Edwin Morgan's 'Message Clear". In: Texts and Minds. Papers in Cognitive 
Poetics and Rhetoric. Ed. Alina Kwiatkowska. (125-138). Frankfurt am Main: Peter Lang.

Kocot, Monika (2016a). “Dialogic Imagination: Edwin Morgan and Russian Modernism. Beyond Sense Through Laughter". In: Scottish Culture: Dialogue and Self-Expression. Eds. Aniela Korzeniowska and Izabela Szymańska. (21-37). Warszawa: Semper.

Kocot, Monika (2016b). Playing Games of Sense in Edwin Morgan's Writing. Frankfurt am Main: Peter Lang.

Markowski, Marek Paweł (1999). Pragnienie obecności. Filozofie reprezentacji od Platona do Kartezjusza. Gdańsk: słowo/ obraz terytoria.

Marx, William (2004). Lesarrière gardes au XX siècle. Paris: Presses Universitaires de France.

McGonigal, James (2012). Beyond the Last Dragon: A Life of Edwin Morgan. Dingwall: Sandstone Press Ltd.

Morgan, Edwin (1974). Essays. Cheadle Hulme, Cheadle: Carcanet Press.

Morgan, Edwin (1988). Themes on a Variation. Manchester: Carcanet.

Morgan, Edwin (1990). Nothing Not Giving Messages: Reflections on Work and Life. Ed. Hamish Whyte. Edinburgh: Polygon.

Morgan, Edwin (1996). Collected Poems. Manchester: Carcanet.

Nicholson, Colin (2002). Inventions of Modernity. Manchester: Manchester University Press.

Perloff, Marjorie (2010). Unoriginal Genius: Poetry by Other Means in the New Century. Chicago: The University of Chicago Press.

Ślósarska, Joanna (2005). "Mit i anamorfoza - dialog Ardżuny i Kriszny w Bhagawadgicie". In: Mity, mitologie, mityzacje. Nie tylko w literaturze. Ed. Lidia Wiśniewska. (65-72). Bydgoszcz: Wyd. Uniwersytetu Kazimierza Wielkiego.

Solt, Mary Ellen (1970). Concrete Poetry: A World View. Bloomington: Indiana University Press.

Tange, Hanne (2004). "In a World of Words: Edwin Morgan's Multilingualism. Scottish Studies Review 5 (1): 87-100.

Young, Alan (1980). “Three 'Neo-Moderns': Ian Hamilton Finlay, Edwin Morgan, Christopher Middleton". In: British Poetry Since 1970: A Critical Survey. Eds. Peter Jones and Michael Schmidt. (112-124). New York: Persea Books.

Žižek, Slavoj (1992). Looking Awry: An Introduction to Jacques Lacan Through Popular Culture. Cambridge: MIT Press. 